\title{
KEBIASAAN HYGIENE REMAJA MELAKUKAN PENCEGAHAN PENYAKIT SKABIES DI PESANTREN AL FAJAR KECAMATAN RUMBAI PEKANBARU
}

\author{
Tri Siwi KN, Wiwik Norlita \\ Fakultas MIPA dan Kesehatan Universitas Muhammadiyah Riau \\ e-mail:trisiwi@umri.ac.id
}

\begin{abstract}
Scabies is a common skin disease in tropical countries that are endemic. Scabies prevalence worldwide is reported to be about 300 million cases of year. Indonesia has a prevalence of scabies in 2016 of 4.60-12.9 percent. Based on reports from policlinic pesantren Darel Hikmah Pekanbaru, many santri who experience scabies disease in recent years. In 2009 there were 98 cases and in 2010 it increased to 115 cases. Al Fajar Orphanage is one of the communities that are vulnerable to the incidence of scabies diseases. In the last two years there have been 9 cases of skabies in the santri in the orphanage. This study aims to find out how the habit of teenage hygiene to prevent scabies at Al-Fajar Orphanage Muara Fajar Village, Rumbai District. This research use descriptive with junlah sampel 30 responden. Methods of data collection using questionnaires and. The results of the questionnaire showed that most adolescents had poor hygiene habits of 17 respondents (56.7 percent) with mean $<12$ and adolescents with good hygiene habits of 13 respondents (43.33 percent) with mean $\geq 12$. Based on this research, it can be concluded that the habit of teenage hygiene in preventing scabies disease is still very need to be improved and require more intensive attention from pesantren teacher so that it can reduce the incidence of scabies disease in Al Fajar orphanage.
\end{abstract}

Keywords: hygiene habit, adolescent, prevention of scabies

\section{PENDAHULUAN}

Skabies merupakan penyakit infeksi parasit pada kulit yang disebabkan oleh masuknya organisme dan adanya sensitisasi sarcoptes scabiei var homonis termasuk ordo acariformes, family sarcoptidae, Genus sarcoptes. (Handoko, 2008 dalam Maulina, 2016).

Terjadinya penyakit Skabies dapat dipengaruhi oleh beberapa faktor antara lain faktor social ekonomi yang rendah, padat, tingkat pengetahuan, usia, kontak dengan penderita baik langsung maupun tidak langsung maupun kebiasaan hygienis yang buruk. Tanda kardinal dari penyakit scabies yaitu terasa gatal pada malam hari terutama dibagian sela-sela jari tangan, di bawah ketiak, pinggang, alat kelamin, sekeliling siku, dan areola. Hal ini disebabkan karena aktivitas tungau meningkat pada suhu yang lebih lembab dan panas. Adanya terowongan pada tempat-tempat predileksi yang berwarna putih atau keabu-abuan, berbentuk garis lurus atau berkelok dan pada ujung terowongan ditemukan vesikel. Penyakit ini dapat menyerang manusia secara berkelompok, apabila ada salah satu dari anggota keluarga yang terkena scabies, maka seluruh anggota keluarga biasanya juga akan akan terkena infeksi scabies (Djuanda, 2008 \& Akmal, 2013).

Insiden penyakit Skabies sangat tinggi terjadi di negara-negara tropis yang merupakan negara endemik. Prevalensi skabies di seluruh dunia dilaporkan sekitar 300 juta kasus per tahun (Wijaya, 2011). Angka kejadian skabies di pulau Pinang Malaysia relative banyak pada anak usia 10-12 tahun 
yang berjumlah 31 persen. Sedangkan prevalensi scabies di Negara India sebesar 20,4 persen ( Hilma 2014), di Brazil Amerika Selatan prevalensi skabies mencapai 18 persen. Prevalensi penyakit skabies di Indonesia sebesar 4,60-12,95 persen dan penyakit ini menduduki urutan ke tiga dari dua belas penyakit kulit tersering (Notobroto, 2009, dalam Desmawati, et al, 2015).

Panti asuhan Al Fajar yang ada di Kecamatan Rumbai Kota Pekanbaru merupakan salah satu komunitas yang rentan dengan kejadian penyakit skabies. Dua tahun terakhir ini terdapat 9 kasus skabies pada santri yang ada di panti asuhan. Hal ini sangat berkaitan dengan faktor kebiasaan hygiene santri dalam menjalankan aktivitas sehari-hari. Penyakit skabies dapat dicegah dengan meningkatkan kebiasaan kebersihan baik itu kebersihan diri maupun lingkungan sekitarnya. Kebersihan diri yang harus diperhatikan remaja dalam pencegahan penyakit skabies seperti kebiasaan mencuci tangan yang baik dan benar, frekuensi mandi setiap hari, frekuensi mengganti pakaian, tidak memakai handuk secara bersamaan, tidak menggunakan sabun mandi batangan secara bersama-sama, tidak menggunakan pakaian secara bersamasama, tidak saling bertukar benda pribadi seperti sisir, jam tangan, memotong kuku secara rutin, frekuensi mengganti sprei tempat tidur lebih ditingkatkan yaitu seminggu sekali, tidak merendam pakaian di satukan dengan pakaian santri lainnya dan tidak melakukan kontak langsung dengan penderita penyakit skabies.

Selain itu mencegah terjadinya penyakit scabies juga dapat dilakukan dengan menjaga sanitasi lingkungan dengan cara membersihkan jendela dan membukanya setiap hari, membersihkan perabotan milik santri, menyapu dan mengepel lantai, mencuci peralatan makanan langsung setelah selesai makan, membersihkan kamar, tidak menggantung pakaian setelah dipakai, meningkatkan pencahayaan matahari masuk kedalam kamar, frekuensi membersihkan kamar mandi, serta membuang sampah (Wijaya, 2011 dalam Desmawati et al., 2015 \& Andayani, 2013).

\section{METODOLOGI PENELITIAN}

Penelitian ini menggunakan pendekatan deskriptif analitik yang menjelaskan bagaimana kebiasaan hygiene remaja melakukan pencegahan scabies di Panti Asuhan Al Fajar dengan tehnik pengambilan sampel total sampling yang berjumlah 30 responden. Prosedur penelitian yang dilakukan meliputi pengumpulan data melalui kuesioner, wawancara dengan ibu asrama dan observasi kondisi kesehatan tubuh santri dan observasi lingkungan. Sebelum memberikan kuesioner, terlebih dahulu peneliti memberikan penjelasan tentang tujuan dan cara pengisian kuesioner kepada responden. Kemudian peneliti mengumpulkan kembali kuesioner setelah diisi responden, kemudian memeriksa kembali kelengkapan dari kuesioner tersebut. setelah data diperoleh diolah oleh peneliti menggunakan SPSS untuk mengetahui sejauh mana kebiasaan hygiene responden, data dimasukkan ke dalam hitungan mean/median dengan standar objektif sebagai berikut :

Baik : Nilai $\geq$ Mean

Kurang Baik : Nilai < Mean

\section{HASIL PENELITIAN DAN} PEMBAHASAN

Tabel 1 Distribusi frekuensi umur responden

\begin{tabular}{crcc}
\hline NO & \multicolumn{1}{r}{ Umur/th } & f & $\%$ \\
\hline 1 & Remaja awal & $\mathbf{1 8}$ & $\mathbf{5 0 , 0}$ \\
2 & Remaja & 9 & 40,1 \\
3 & menengah & 3 & 9,9 \\
& Remaja akhir & & \\
\hline
\end{tabular}




\section{Total}

30

100

Berdasarkan tabel 1 dapat diketahui bahwa umur responden mayoritas remaja awal (10 14) tahun yaitu sebanyak 18 responden $(50,0 \%)$.

Tabel 2 Distribusi frekuensi jenis kelamin responden

\begin{tabular}{cccc}
\hline No & Jenis kelamin & f & \% \\
\hline 1 & Laki-laki & 14 & 46,7 \\
2 & Perempuan & 16 & 53,3 \\
\hline & Total & $\mathbf{3 0}$ & $\mathbf{1 0 0}$ \\
\hline
\end{tabular}

Berdasarkan tabel 2 jenis kelamin responden mayoritas perempuan sebanyak 16 responden $(53,3 \%)$.

Tabel 3 Distribusi frekuensi tingkat pendidikan responden

\begin{tabular}{|c|c|c|c|}
\hline No & Tingkat pendidikan & $\mathbf{f}$ & $\%$ \\
\hline 1 & SD & 8 & 26,7 \\
\hline 2 & SMP & 12 & 40,0 \\
\hline 3 & SMA & 7 & 23,3 \\
\hline 4 & Tamat SMA & 3 & 10,0 \\
\hline & Total & & 00 \\
\hline
\end{tabular}

Berdasarkan tabel 1.3 diperoleh hasil bahwa pendidikan responden mayoritas SMP sebanyak 12 responden $(40,0 \%)$.

Tabel 4 Distribusi frekuensi responden yang pernah mendapatkan informasi

\begin{tabular}{cccc}
\hline No & $\begin{array}{c}\text { Mendapatkan } \\
\text { informasi }\end{array}$ & f & $\mathbf{( \% )}$ \\
\hline 1 & Ya & 7 & 23,3 \\
2 & Tidak & 23 & 76,7 \\
\hline & Total & $\mathbf{3 0}$ & $\mathbf{1 0 0}$ \\
\hline
\end{tabular}

Berdasarkan tabel 4 di peroleh data mayoritas responden tidak mendapatkan informasi sebanyak 23 responden $(76,7 \%)$.

Tabel 5 Distribusi frekuensi sumber informasi yang pernah diperoleh responden tentang penyakit skabies

\begin{tabular}{llcc}
\hline No & Sumber informasi & f & \% \\
\hline 1 & Ibu asrama & 4 & 57,14 \\
2 & Media elektronik & 3 & 42,86 \\
\hline
\end{tabular}

Berdasarkan tabel 5 menunjukkan bahwa responden mayoritas memperoleh informasi dari ibu asrama dengan responden sebanyak 4 responden $(57,14 \%)$.

Tabel 6 Distribusi frekuensi riwayat responden terkena Penyakit Skabies

\begin{tabular}{cccc}
\hline No & $\begin{array}{c}\text { Pernah } \\
\text { mengalami skabies }\end{array}$ & f & $\mathbf{( \% )}$ \\
\hline 1 & Ya & 9 & 30 \\
2 & Tidak & 21 & 70 \\
\hline & Total & $\mathbf{3 0}$ & $\mathbf{1 0 0}$ \\
\hline
\end{tabular}

Berdasarkan tabel 6 menunjukkan responden yang pernah mengalami penyakit skabies penyakit skabies sebanyak 9 responden $(30 \%)$

Tabel 7 Kebiasaan hygiene responden melakukan pencegahan skabies

\begin{tabular}{cccc}
\hline No & Perilaku & f & \% \\
\hline 1 & Baik & 13 & 43,3 \\
2 & Kurang Baik & 17 & 56,7 \\
\hline & Total & $\mathbf{3 0}$ & $\mathbf{1 0 0}$ \\
\hline
\end{tabular}

Tabel 7 diketahui bahwa sebagian besar kebiasaaan hygiene responden kurang baik sebanyak 17 responden $(56,7 \%)$.

Berdasarkan hasil wawancara peneliti terhadap beberapa responden pada saat melakukan penelitian, mayoritas responden mengatakan tidak mengetahui informasi tentang penyakit skabies dan pencegahan skabies karena padatnya jadwal aktifitas responden seperti bersekolah, mengerjakan tugas rumah, mengaji malam bersama serta kegiatan lainnya. Sehingga hampir tidak ada waktu untuk mencari informasi maupun keterbatasan mendapatkan informasi dari tenaga kesehatan.

Selain faktor informasi, menurut peneliti faktor pengalaman responden juga mempengaruhi kebiasaan remaja berperilaku 
hidup sehat, karena seseorang yang pernah mengalami akan tahu bagaimana cara untuk mengatasi masalah kesehatan yang pernah dialami , karena responden mayoritas belum pernah mengalami gejala penyakit skabies.

Menurut Notoatmodjo, 2010, pengalaman dapat menjadi salah satu indikator pengetahuan seseorang yang akan mempengaruhi perilaku atau kebiasaan seseorang menjalankan pola hidup bersih dan sehat. Hasil penelitian Ma'rufi (2005) di Pondok Pesantren X di Lamongan, personal hygiene merupakan faktor yang berperan dalam penularan skabies. Terdapat $63 \%$ santri mempunyai personal hygiene yang buruk dengan prevalensi skabies $73,70 \%$. Personal hygiene meliputi kebiasaan mencuci tangan, pemakaian handuk yang bersamaan, frekuensi mandi, frekuensi mengganti pakaian, frekuensi mengganti sprei tempat tidur, dan kebiasaan kontak langsung dengan penderita skabies, kebiasaan yang lain juga seperti menggunakan sabun batangan secara bersama-sama. Hal ini didukung oleh penelitian Yasin tahun 2009 yang berjudul " Prevalensi skabies dan faktorfaktor yang mempengaruhinya pada siswa siswi pondok pesantren Darul Mujahadah Kabupaten Tegal" menjelaskan bahwa dalam kaitannya dengan kejadian skabies pada seseoarang, pengalaman keterpaparan sangat berperan karena mereka yang berumur lebih tinggi dan mempunyai pengalaman terhadap skabies tentu mereka akan lebih tahu cara pencegahan serta penularannya. Selain itu juga Djuanda, 2008, menjelaskan bahwa di beberapa negara yang sedang berkembang prevalensi skabies pada populasi umum cenderung tinggi pada anak-anak serta remaja.

Dengan demikian diharapkan kepada responden agar lebih rajin mencari informasi yang akurat tentang penyakit scabies dan setelah mendapatkan informasi responden membiasakan diri untuk melakukan pola hidup bersih dan sehat secara teratur. Selain itu untuk pengelola Panti Asuhan diharapkan lebih kooperatif melakukan koordinasi dengan fasilitas pelayanan kesehatan setempat untuk mengadakan kegiatan pemberian pendidikan kesehatan dan bimbingan kesehatan kepada santri yang ada di panti asuhan untuk meningkatkan pengetahuan para santri tentang ilmu kesehatan yang dapat diaplikasikan dalam kehidupan sehari-hari untuk meningkatkan derajat kesehatan secara maksimal.

\section{KESIMPULAN DAN SARAN}

Berdasarkan hasil penelitian yang telah dilaksanakan peneliti terhadap 30 responden diperoleh hasil sebagai berikut :

sebagian besar responden memiliki kebiasaan hygiene melakukan pencegahan skabies kurang baik sebanyak 17 responden (56,7 persen) dan yang memiliki kebiasaan hygiene baik sebanyak 13 responden (43,3persen).

Kebiasaan hygiene responden yang kurang baik tersebut kemungkinan dapat disebabkan oleh faktor keterbatasan informasi karena tidak ada penjadwalan khusus kegiatan pemberian pendidikan kesehatan di Panti asuhan dan pengalaman responden pernah/mengalami penyakit skabies sebelumnya.

\section{DAFTAR PUSTAKA}

Akmal suci chairiya et, al (2013). " Hubungan Personal Hygiene Dengan Kejadian Skabies Di Pondok Pendidikan Islam Darul Ulum, Palarik Air Pacah, Kecamatan Koto Tangah Padang Tahun 2013" jurnal kesehatan andalas.2013.

Andayani. (2013). “Perilaku santri dalam upaya pencegahan penyakit skabies di pondok pesantren ulumu qur'an Stabat". 
Desmawati, Ari, P.D., \& Oswati, H. (2015). Machfoed, Ircham. 2009. Metodologi "Hubungan personal hygiene dan sanitasi lingkungan dengan kejadian skabies di pondok pesantren AlKautsar Pekanbaru". JOM (volume 2 nomor 1).

Djuanda, A. (2008). Ilmu penyakit kulit dan kelamin fakultas kedokteran universitas indonesia. Jakarta: Universitas Indonesia.

Hilma, UD., Ghazali, L.(2014). Faktor-faktor yang mempengaruhi kejadian skabies di pondok pesantren mlangi Nogotirto gampling Sleman Yogyakarta.

Maulina et,al (2016). “ Perilaku pencegahan penyakit terhadap kejadian skabies pada santri pondok pesantren AlFalah putera Banjarbaru'.Jurnal penelitian Dunia keperawatan volume Penelitian Bidang Kesehatan, Keperawatan, Kebidanan, Kedokteran. Yogyakarta: Fitramaya.

Notoatmodjo, Soekidjo. 2010. Ilmu Prilaku Kesehatan. Jakarta: Rineka Cipta.

Wijaya, Y. (2011). Faktor-faktor yang berhubungan dengan kejadian skabies pada santri di pondok pesantren Al-Makmur Tungkar Kabupaten 50 Kota. Di peroleh tanggal 25 Mei 2017 dari http://repository.uinjkt.ac.id

Yasin. (2009). Prevalensi skabies dan faktorfaktor yang mempengaruhinya pada siswi pondok pesantren Darul Mujahadah Kabupaten Tegal. Di peroleh tanggal 27Januari 2017 dari http://repository.ac.id 